\title{
LINGKUNGAN HIDUP DAN MANUSIA (Kajian Falsafah Kalam)
}

\author{
Burhanuddin Yusuf \\ Dosen Aqidah \& Filsafat Islam \\ Fakultas Ushuluddin, Filsafat \& Politik \\ UIN Alauddin Makassar \\ e-mail: yusuf.burhanuddin@gmail.com
}

\begin{abstract}
Abstrak
Konsentrasi pemikiran manusia pada diri sejak masa renaissance yang menghsilkan watak kerakusan dalam mengeksplorasi alam menyebabkan terjadinya ketidakseimbangan kehidupan di Bumi. Para ahli kalam modern terpanggil untuk mengambil bagian mengkaji persoalan Lingkungan Hidup ini dari kacamata kepercayaan agama Islam, dan ternyata ditemukan bahwa alam bukan sekedar diberikan begitu saja oleh Sang Pencipta kepada manusia, tapi juga amanah memakmurkannya yang harus dipertanggungjawabkan di hadapan-Nya kelak.
\end{abstract}

\section{Keywords:}

Lingkungan Hidup, Manusia, Falsafah Kalam

\section{PENGANTAR}

Menurut Alquran, Bumi diciptakan oleh Allah swt. adalah untuk kepentingan hidup manusia الذى خلق لكم ما فى الأرض جميعًا هو (QS. Al-Baqarah/2:29). Artinya, bumi bagi manusia adalah sarana hidup. Dari bumi (tanah) Allah menciptakan manusia, dari hasil-hasil yang keluar dari perut bumi, manusia beroleh sandang, papan dan pangan, dan kelak manusia setelah kembali kepada Tuhannya, jasadnya juga akan dikembalikan ke bumi.

Kalau bumi menjadi sesuatu yang sangat berarti bagi kehidupan manusia dalam arti manuia banyak tergantung kepadanya منها خلقنكم وفيها ننعيدكم ومنها نخرجكم تارنا هُخرى (QS Thaha/2:20) maka seyogyanya manusia memiliki tanggungjawab untuk menjaga kelestariannya. Manusia seharusnya berkepentingan untuk memelihara keberlangsungan eksistensi bumi, karena manusia mau tidak mau kehidupannya tergantung kepada sejauh mana bumi itu memiliki kemampuan menyediakan sarana dan prasarana bagi kehidupan manusia.

Kaitan bumi sebagai penyedia sarana dan prasarana hidup dan kehidupan manusia, maka ada beberapa hal yang perlu mendapatkan perhatian khusus, terutama unsur-unsur yang secara nyata langsung berhubungan dengan kepentingan hidup manusia itu sendiri. Diantara unsur-unsur penting yang perlu digaris bawahi tersebut adalah udara, air, tanah dn hal-hal yang secara langsung berkaitan dengan tiga unsur tersebut. 
Dalam pembahasan-pembahasan tentang hubungan antara ketiga unsur pokok tersebut dengan kehidupan manusia, dikenal istilah yang cukup popular, yakni "Lingkungan Hidup". Istilah lingkungan hidup yang secara popular biasa dimaknakan dengan semua hal yang berhubungan dengan kehidupan di bumi, yang setiap unsurnya saling kait mengait, saling bergantung dan saling pengaruh mempengaruhi.

Tulisan ini akan mengangkat persoalan Lingkungan Hidup ini dari sudut pandang Falsafah Teologi Islam. Sudah barang tentu alat yang dijadikan sebagai pengkaji obyeknya adalah Falsafah Kalam yang popular di kalangan ilmuan Islam pasca abad pertengahan. Di antara ciri era ini adalah terjadinya pergumulan pemikiran antara system pemikiran kalam tradisional dengan sentuhan kondisional praktis kaum muslimin akibat dari sentuhan kemajuan ilmu pengetahuan dan teknologi yang secara nyata laju pertumbuhan dan perkembangannya sangat tidak seimbang dengan pertumbuhan pemikiran kalam itu sendiri.

Untuk mengarahkan pembahasan, maka yang menjadi pokok kajiannya adalah apakah sesunggunya lingkungan hidup itu, bagaimana kaitan antara satu unsur dengan unsur hidup lainnya serta bagaimana peran sekaligus tanggungjawab manusia sebagai khalifatullah fi al-ardh.

\section{FALSAFAH TEOLOGI ISLAM DAN LINGKUNGAN HDUP.}

\section{A. Falsafah.}

Menurut Oemar Amin Husein, kata dan istilah "filsafat" bukan merupakan asli milik orang dan Bahasa Arab, sungguhpun di kalangan mereka dikenal istilah "Hikmah" dan "Hukama". Kata dan istilah "falsafah" muncul di tengah-tengah mereka setelah terjadi kontak dengan bangsa dan budaya Yunani dan juga budaya-budaya lainnya seperti budaya India, budaya Mesir Kuno dan lainnya. Orang-orang Arab mengutip istilah Yunani dan menyerapnya menjadi bagian dari kosa kata mereka dengan sedikit penyesuaian “ فلسفةً الفلسفةُ". Selanjutnya, kata tersebut dalam istilah Bahasa Indonesia disebut sebagai "filsafat" ${ }^{1}$

Masuknya disiplin filsafat ke dunia Islam didahului oleh gerakan penerjemahan. Penerjemahan di sini adalah buku-buku filsafat dengan berbagai keturunannya dalam bahasa Yunani diterjemahkan ke dalam Bahasa Arab. Gerakan penerjemahan ini terutama pada masa daulah Abbasiyah, sekitar Abad I s.d. VII Hijriyah dengan puncak kejayaannya pada masa pemerintahan khalifah al-Makmun, tahun 198 - 218H/754 $775 \mathrm{M}^{2}$

Ketertarikan orang-orang Arab Islam mempelajari dan mengembangkan "filsafat" sesungguhnya adalah karena kebutuhan praktis, dan karena kedua sumber Islam dan alHadist tidak menutup jalan ke arah itu, bahkan oleh para filosof Muslim, kedua sumber dasar Islam tersebut dipahami memerintahkannya. Al- Kindi dan Ibnu Rusyd secara

\footnotetext{
${ }^{1}$ Oemar Amin Husein, Filsafat Islam (Jakarta: Bulan Bintang, 1975), h. 11-12.

2 Abdul Azis Dahlan "Filsafat" dalam Taufik Abdullah (Eds.) Ensiklopedi Tematis Islam, Pemikiran dan Peradaban (Jakarta: Ichtiar Baru Van Hoeve, 2002), h. 177.
} 
tegas menyatakan bahwa kedua sumber dasar tersebut justru mewajibkannya. ${ }^{3}$ Kebutuhan praktis karena umat Islam berhadapan dengan masyarakat yang memiliki tingkat peradaban dan kebudayaannya lebih tinggi dari masyarakat Arab Islam, sementra di sisi lainnya, orang-orang Arab Islam harus menunjukkan ketinggian, keistimewaan dan kebenaran Islam kepada mereka. Untuk maksud itu semua, orang Arab Islam harus mampu mengemukakan argument rasional, dan itu ada pada filsafat. Perlu dicatat. Bahwa wilayah kekuasaan Islam pada masa daulan Abbasiyah tersebut sudah jauh keluar dari jazirah Arabiyah.

Filsafat karena itu, tidak bertentangan dengan Islam, justru dengan filsafat, kebenaran dan keluhuran Islam sebagai agama "yang ليعلُوا و لَا يُعْلى عليه" dapat ditampilkan ke seluruh umat manusia, karena memang, Islam adalah "rahmatan li al- 'alamin"

\section{B. Kalam/Teologi Islam.}

Secara etimologi dapat dijelaskan bahwa kata teology atau teologi dalam Bahasa Indonesia bersumber dari Bahasa Latin, sementara bahasa latin itu sendiri akarnya adalah dari bahasa Grik Tua. Dalam bahasa Grik Tua dan Grik Romawi, kata 'theologia' terdiri atas patahan kata 'theo' dan 'logos.' Kata 'Theo' dalam pengertian Bahasa Grik tadi adalah kata panggilan untuk Dewa atau para Dewa (Theos). Selanjutnya, kata 'logos' dalam Bahasa Grik berarti akal, wacana, doktrin, teori atau sicience. ${ }^{4}$ Selanjutnya kata tersebut beralih ke Bahasa Inggris, menjadi "theology" dimaknakan dengan 'ilmu agama" atau sedikit yang lebih rinci, dimaknakan dengan 'formal study of the nature of God and of the foundations of religious belief,' 6 jadi suatu ilmu yang secara khusus membicarakan tentang dasar-dasar kepercayaan dari suatu kepercayaan atau agama.

Menurut Lorens Bagus, pada awalnya, teologi dianggap bersangkutan dengan mitos atau mitologi; Hesiodos dan Orpheus adalah contoh terdepan untuk arti tersebut. ${ }^{7}$ Selanjutnya, Lorens menyatakan bahwa Pseudo-Dionysius membedakan antara teologi positif (berdasarkan Alkitab), teologi negative dan teologi superlative (sesuai dengan pandangan Neoplatonik tentang Allah sebagai yang 'ter' dalam segala segi). Karena tiada satupun pendekatan-pendekatan tersebut mencukupi, akhirnya dianjurkan satu bentuk teologi baru yang disebut teologi mistik. $^{8}$

${ }^{3}$ Oemar Amin Husein, Filsafat Islam., h. 73-74 dan A Hanafi, Pengantar Filsafat Islam (Jakarta: Bulan Bintang: 1976), h. 241-243. Lihat juga Abdul Azis Dahlan "Filsafat" dalam Taufik Abdullah (Eds.) Ensiklopedi Tematis Islam, Pemikiran dan Peradaban., h. 210.

${ }^{4}$ Lorens Bagus, Kamus Filsafat (Jakarta: Gramedia, 1996), h. 1090. Bandingkan dengan Joesoef Sou’yb, Perkembangan Teologi Modern (Jakarta: Rimbow, 1987), h. 1-2. 586.

5 John M Echols dan Hassan Shadaly, Kamus Inggris Indonesia (Jakarta: Gramedia, 1988), h.

${ }^{6}$ AS Hornby (Eds.) Oxford Advanced Learner's Disctionary of Current English (Oxford: Oxford University Press, 1986), h. 895-896.

${ }^{7}$ Lorens Bagus, Kamus Filsafat

${ }^{8}$ AS Hornby (Eds.) Oxford Advanced Learner's Disctionary of Current English 
Menurut Joesoef Sou'yb, kata 'theologia' itu mengandung makna sebagai suatu ajaran pokok atau sebuah teori atau sebuah ilmu tentang permasalahan Tuhan dalam pengertian yang seluas-luasnya, atau dengan kata lain, suatu disiplin ilmu yang berbicara tentang permasalahan ilahiyat. ${ }^{9}$ Kalau demikian, maka sesungguhnya teologi itu adalah bagian dari filsafat, karena obyek dari filsafat itu sendiri adalah tentang 'yang ada dan yang mungkin ada ${ }^{10}$ Yang ada, baik yang ada secara mutlak dalam pengertian ada dengan sendirinya dan tidak tergantung kepada selain dirinya sendiri (dalam Bahasa agama Tuhan), maupun yang ada tidak mutlak, karena keberadaannya tergantung kepada sesuatu diluar dirinya (dalam Bahasa agama: makhluk/alam maujudat).

Kalau demikian, maka dapat dipahami bahwa ada teologi yang berbasis pemikiran semata-mata (berbasis filsafat) dan ada teologi yang berbasis pada ajaran atau nash agama. ${ }^{11}$ Dalam hal ini setiap agama mempercayai adanya Tuhan dan mengakui adanya tata hubungan antara Tuhan dengan makhluk-Nya, dan itu masuk dalam wilayah pembahasan teologi. Kalau demikian halnya, maka setiap agama memiliki konsep teologi sendiri-sendiri. Ada teologi Kristen, teologi Katholik, teologi Hindu, teologi Budha, teologi Yahudi, teologi Konghuchu, dan ada teologi Islam. ${ }^{12}$

Dalam literature Islam, dikenal beberapa istilah atau nama yang berkaitan dengan ilmu pengetahuan yang membahas tentang dasar-dasar kepercayaan Islam. Diantaranya ilmu Aqidah, Ilmu Tauhid, Ilmu Kalam dan ilmu Ushuluddin. Ilmu Aqidah dan Ilmu Tauhid dalam pembahasannya terlihat lebih menitik beratkan pada upaya mengeksplorasi dasar kepercayaan Islam melalui kajian nash اعلم أنّ علم التوحيد هو علم يبحث) فيه ان اثبات العقاعد الدنيّة بالأدلّة اليقنيّة)

Berbeda dari Ilmu Tauhid dan Ilmu Aqidah, Ilmu Kalam atau Teologi Islam, juga mengeksplorasi kepercayaan Islam, dan membangunnya di atas bangunan argumentasi rasional, logika filsafat. Tidak heran jika Ilmu Kalam biasa juga disebut sebagai “Filsafat Aqidah", Flsafah Kalam dan seterusnya. علم الكلآم هو علم يتضمّن الحجاج عن) العقائد الايمانيّة بالأدلّة العقليّة)

Teologi Islam Klasik pada umumnya membahas tentang dasar-dasar kepercayaan dalam Islam. Dasar-dasar kepercayaan Islam dikenal dengan istilah Rukun Iman, terdiri atas enam unsur, yakni Percaya kepada Keesaan Allah swt., percaya kepada adanya Malaikat-malaikat Allah, percaya kepada Kitab-kitab Allah, percaya kepada Rasul-rasul Allah, percaya kepada adanya hari akhirat dan percaya kepada takdir Allah swt. Secara umum dapat dicatat sebagai upaya mengungkap dasar-dasar kepercayaan Islam dengan mengeksplorasi sumber-sumber nash. Agaknya tidak terlalu

${ }^{9}$ Joesoef Sou'yb, Perkembangan Teologi Modern (Jakarta: Rimbow, 1987), h. 2.

${ }^{10}$ Nihaya, Filsafat Umum, dari Yunani sampai Modern (Makassar: T. Pen., 1999), h. 19

${ }^{11}$ Abdul Asiz Dahlan, Sejarah Perkembangan Pemikiran dalam Islam (Jakarta: Beunebi Cipta, 1987), h. 13.

${ }^{12}$ Abdul Asiz Dahlan, Sejarah Perkembangan Pemikiran dalam Islam

13 Pendapat Al-Jisr al-Tarabulusuri dalam Al-Husun al-Humadiyyah sebagaimana dikutip oleh Abdul Asiz Dahlan, Sejarah Perkembangan Pemikiran dalam Islam, h. 16

${ }^{14}$ Pendapat Ibnu Khaldun dalam Al-Muqaddamah sebagaimana dikutip oleh Abdul Asiz Dahlan, Sejarah Perkembangan Pemikiran dalam Islam, h. 15 
berlebihan jika dikatakan bahwa pemaparan materi yang demikian lebih terkesan sebagai doktrin ajaran daripada ilmu pengetahuan tentang aqidah Islam.

Keenam prinsip dasar kepercayaan Islam yang terangkum dalam Rukun Iman tersebut didasarkan pada hadist Rasulullah saw. yang diriwayatkan oleh imam Muslim sebagai berikut:

$$
\begin{aligned}
& \text { عن عمر بن الخطاب رضي الله عنه قال .......... قال : أخبرني عن الإيمان قال " أن تؤمن بالله } \\
& \text { وملائكته وكتبه ورسله واليوم الآخر وتؤمن بالقدر خيره وشره " قال : صدقت ....... }
\end{aligned}
$$

Artinya:

Dari Umar bin al-Khattab, ia berkata .......... orang itu kemudian bertanya: Khabarkanlah kepadaku tentang iman. Rasulullah saw bersabda, Iman adalah bahwa engkau percaya kepada Allah, kepada malaikat-malaikat-Nya, Kitabkitab-Nya, rasul-rasul-Nya, hari akhirat dan engkau percaya tentang takdir baik dan buruk-Nya. Ia (malaikat Jibril) berkata, "engkau benar"........

Dari enam unsur dasar tersebut di atas, pada hakikatnya hanya mengacu pada satu unsur saja, yaitu Allah swt., yakni tentang penerimaan atau penyaksian manusia akan "keesaan Allah swt." Memang, Alquran menyatakan bahwa dulu (di alam arwah), sebelum manusia disatukan dengan jasadnya, mereka sudah diminta penyaksiannya tentang Allah yang Esa itu, dan mereka menerimanya. Ini terlihat pada firman Allah Swt. Pada QS. Al-A'raf (7) 172:

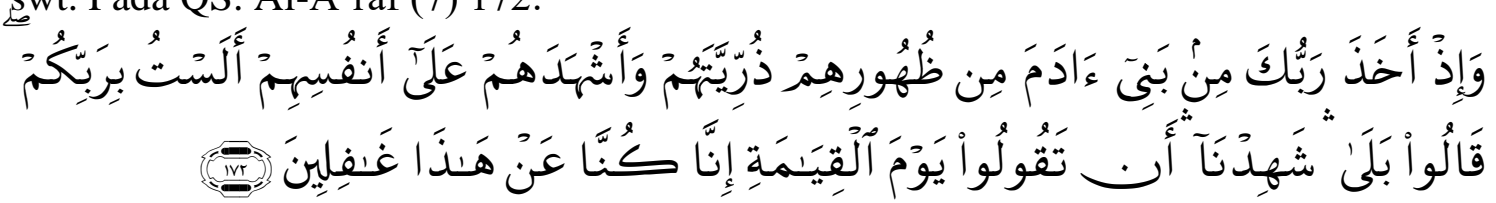

Terjemahnya:

Dan (ingatlah), ketika Tuhanmu mengeluarkan keturunan anak-anak Adam dari sulbi mereka dan Allah mengambil kesaksian terhadap jiwa mereka (seraya berfirman): "Bukankah Aku ini Tuhanmu?" Mereka menjawab: "Betul (Engkau Tuhan kami), kami menjadi saksi". (Kami lakukan yang demikian itu) agar di hari kiamat kamu tidak mengatakan: "Sesungguhnya kami (bani Adam) adalah orang-orang yang lengah terhadap ini (keesaan Tuhan)",

Mengomentari ayat tersebut, Prof. DR. H. M. Quraisy Syihab, MA., mengemukakan bahwa manusia pada fitrahnya senantiasa merasakan kehadiran Tuhan pada dirinya, karena itu adalah fitrah bawaannya. Keabsenan perasaan ini hanya terjadi jika manusia terhalang oleh dosa-dosa yang digelimanginya. Hatinya terbutakakan oleh kegelapan dosa-dosa itu, sehingga tidak mampu merasakan dan melihat yang benar itu sebagai kebenaran dan yang salah itu sebagai sesuatu yang harus dihindari. ${ }^{16}$

\footnotetext{
${ }^{15}$ Shahih Muslim, "Hadist No 2 Kitab Iman” CD Ensiclopedi al-Qur'an dan Hadist, Pustaka Raihan" diunduh pada hari Ahad, 13 Juli 2015.

${ }^{16}$ Quraisy Shihab, Wawasan Al-Qur"an (Jakarta: Mizan, 1996), h. 17-18.
} 
Selanjutnya Quraisy menggaris bawahi bahwa Alquran menegaskan Prinsip "Tauhid" sebagai prinisp dasar dari semua agama samawi ${ }^{17}$ yang dibawa oleh seluruh Nabi dan Rasul ke permukaan bumi ini untuk umat mereka masing-masing. Penegasan ini diperkuat dengan mengutip beberapa nash Alquran, antara lain QS. Fushshilat (41): 30, QS. Al-Anbiya (21): 25, QS. Al-A'raf (7): 59, 65, 73 dan 85, QS. Thaha (20): 13 14, QS. Al-Ma'idah (5): 72 dan lainnya. ${ }^{18}$

Pada ilmu Kalam dan ilmu Ushuluddin klasik, sungguhpun obyek pembahasannya sudah diperlebar dan masuk ke wilayah yang lebih rinci, namun tetap tidak lepas dari enam prinsip dasar tersebut di atas. Ini tergambar pada antara lain seperti yang dikemukakan oleh Ibnu Khaldun (1332-1402), Theologi Islam itu harus mampu memberi bukti-bukti yang logis dan akurat atas apa yang dikemukakan oleh Alquran dan Alhadist berkaitan dengan Rukun Iman dalam Islam. ${ }^{19}$ Hal tersebut lebih dipertajam lagi oleh Prof. DR. M Amin Abdullah yang mengemukakan bahwa pemikiran teologi Islam klasik belum beranjak dari rumusan-rumusan teologi abad pertengahan yang masih terikat pada hal-hal yang bersifat transcendental, dan sangat kurang menyentuh persoalan umat yang sesungghnya sangat perlu mendapatkan sentuhan. ${ }^{20}$

Tidak heran bila pada perkembangan selanjutnya, muncul Theologi Modern di semua agama. Materi yang dibahas pada teologi modern tidak terbatas lagi pada obyek bahasan yang bersifat transcendental sebagaimana pada teologi klasik, tapi telah menyentuh hal-hal yang bersifat praktis. Theologi Modern telah berupaya membawa masalah-masalah Ketuhanan kepada masalah kekinian yang dialami oleh manusia dengan kata lain, telah menyentuh persoalan-persoalan praktis manusia. Hal lain yang tampak pada pembahasan teologi modern yaitu sejumlah kritik tajam atau reinterpretasi atas sejumlah topic bahasan theologi klasik yang dinilai perlu dikembangkan.

Perlu digaris bawahi bahwa teologi Islam modern dalam melakukan reinterpretasi tidaklah tanpa batasan. Para mutakallimin menetapkan sekurangkurangnya empat buah aturan dasar atau asaz yang mengikat mereka, yaitu:

1. Nash (Alquran dan Alhadist) yang bersifat qath'iy tidak dapat dirobah.

2. Penafsiran Ulama Mutaqaddimin, baik di bidang syariah maupun di bidang aqidah dapat ditinjau kembali disesuaikan dengan kondisi kekinian.

3. Alhadist yang tidak bersifat muthawatir dapat ditinjau atau dinilai kembali tentang kebenarannya dengan menyoroti dari berbagai disiplin keilmuan.

4. Shahih Bukhari dan Shahih Muslim dapat ditinjau kembali kesahihannya.

17 Dimaksudkan dengan "Agama Samawi” disini adalah agama yang Allah swt. Turunkan melalui nabi dan Rasul, seperti Agama: Yahudi , Nashrani dan Islam.

${ }^{18}$ Quraisy Shihab, Wawasan Al-Qur"an, h. 18-20.

19 Mulyadi Kartanegara "Ilmu Kalam" dalam Ensiklopedi Tematis Dunia Islam, IV (Jakarta: Ichtiar Baru Van Hoeven, 2002), h. 117 $47-48$.

${ }^{20}$ Amin Abdullah, Falsafah Kalam di Era Post Modernisme (Jakarta: Pustaka Pelajar, 1997), h. 
Beberapa obyek kajian kalam yang dapat ditunjuk sebagai sample berkaitan dengan kritik atau reinterpretasi tersebut sebagai berikut:

1. Adam dan Hawa, apa benar manusia pertama di Bumi?

2. Isa al-Masih diangkat ke langit atau tidak.

3. Al-Mahdi dan isa al-Masih akan turun kembali ke bumi. Permasalahan ini benar atau tidak.

4. Sorga dan Neraka itu apakah di langit atau di dunia

5. Dan lainnya. ${ }^{21}$

Dengan mengacu pada empat asaz dasar tersebut di atas, dan sejalan dengan kebutuhan real masyarakat muslim, maka pada perkembangan selanjutnya, muncullah berbagai cabang teologi dalam Islam menurut bidang-bidang yang bersentuhan dengan keseharian manusia. Diantara yang pantas dikemukakan adalah Teologi Sosial, Teologi Pembangunan, Teologi Perkembangan, Teologi Lingkungan Hidup, Teologi Kesehatan, Teologi Teknik dan banyak seterusnya.

Dalam kenyataan memang Islam tidak melakukan pengklassifikasian urusan dalam hidup manusia. Ajaran Islam memandang bahwa hidup manusia adalah satu kesatuan yang tidak terpisahkan. Bahwa kehidupan dunia ini tidak lepas dari kehidupan akhirat; sebaliknya kehidupan akhirat juga tidak lepas dari kehidupan dunia. Dengan perkataan lain bahwa tidak ada satupun kegiatan manusia yang lepas dari dua dimensi dasar itu. Keduanya adalah bagaikan dua sisi dari satu mata uang.

Pada akhirnya dapat disempulkan bahwa kata atau istilah 'Teologi' mengandung makna ilmu yang berkaitan dengan Tuhan. Semua agama memiliki teologi sendirisendiri. Seperti juga pada agama-agama lainnya, dalam literature Islam dikenal Teologi Islam Kassik dan Teologi Islam Modern. Teologi Islam Klassik berbicara berbagai hal yang berkaitan dengan Allah swt, namun obyek bahasannya masih bersifat transcendental; Berbeda dari itu, pada teologi Islam modern, sudah lebih banyak menyentuh hal-hal yang bersifat praktis, yang menyentuh kehidupan keseharian dari orang-orang Islam. Kalau meminjam sedikit istilah Prof.DR H.M. Quraisy Syihab. MA, para teolog Islam Modern sudah berupaya keras membumikan teologinya.

\section{Falsafah Teologi Islam}

Di Indonesia, sebagai konsekwensi keberhasilan pembangunan yang digalakkan oleh pemerintah dan rakyatnya adalah terjadinya pergeseran-pergeseran di semua lini kehidupan, baik di bidang intelektual maupun di bidang kehidupan keseharian rakyat Indonesia itu sendiri.

Di bidang intelektual, khususnya di lingkungan ilmu-ilmu keislaman, di era tujuh puluhan dan delapan puluhan, misalnya muncul istilah "Teologi Pembangunan"

${ }^{21}$ Informasi lengkap pada persoalan ini dapat dilihat pada Joesoef Sou'yb, Perkembangan Teologi Modern (Jakarta: Rimbow, 1987), h. 108-125. 
yang diperkenalkan oleh Nurcholis Majid, “Teologi Transpormatif” yang diperkenalkan oleh Kuntowijoyo, "Teologi Sosial” yang dipopulerkan oleh Amin Rais dan lainnya. Kesemuanya itu merupakan perwujudan tuntutan dari kenyataan social masyarakat yang merambah kemajuan di segala bidang tercermin dari munculnya gejala desakan untuk keluar dari belenggu-belenggu etimologis yang selama ini mengikat kerangka berfikir mereka.

Ilmu Kalam (klassik) dan Filsafat Islam (klassik) menjadi sesuatu yang kurang diminati, sungguhpun tercantum sebagai mata kuliah pokok di perguruan tinggi Islam, khususnya fakultas Ushuluddin. Hal ini terjadi karena kedua mata kuliah dengan pendekatan etimologi era abad pertengahan sudah dirasakan kurang atau tidak memiliki koneksitas pada kehidupan era kekinian. Dapat difahami dengan munculnya istilahistilah baru tersebut di atas yang menggambarkan upaya menarik falsafah Islam dan kalam (klasik) yang dinilai dan dirasakan terlalu mengawan-awan ditarik untuk dibumikan, sejalan dengan kebutuhan praktis masyarakat muslim yang kian kompleks. ${ }^{22}$

Menurut Amin Abdullah, sebenarnya, jauh sebelum ini, Ibnu Miskawaih (9321030) dan Ibnu Khaldun (1332-1406) pernah berupaya memasukkan pemikiran postif empiris dalam penulisan sejarah Islam dan Arab, namun keduanya tidak pernah berhasil merubah bangunan epistimologi lama. Bahkan hingga memasuki awal abad XIX dan $\mathrm{XX}$, pemikiran yang berbau positif empiris diplesetkan sebagai pengetahuan yang membawa kepada faham materialistic-atheistik. ${ }^{23}$ dari sini juga dapat dipahami kenapa kritik epistimologi yang pernah dilontarkan oleh Ibnu Rusyd (1126-1198) terhadap pemikiran al-Ghazali (1058-1111) tidak pernh mendapat tempat di kalangan muslim sunni orthodox, sehingga kritik tersebut hanya ibarat "menepuk air di dulang",24

Terjadinya dualisme model pemikiran yang begitu tajam, antara tradisi idealisme dengan empiris di wilayah pemikiran Islam klasik dan kontemporer dinilai sebagai salah satu sebab kenapa nash-nash yang berkaitan dengan empiric kealaman seperti langit, bumi, air, tanah, hujan, api, siang, malam dan seterusnya dan nash yang berbau empiric kemanusiaan seperti kelahiran, kematian, siksaan, cinta, kehidupan, keadilan, kesejahteraan, kedamaian dan seterusnya kurang mendapat tempat yang layak.

Menyadari bahwa realitas tuntutan masyarakat muslim akan pentingnya ilmuilmu keislaman bangkit menyongsong dan bahkan kalau perlu menjadi lokomotif kemajuan tamaddun Islam, maka polarisasi tersebut di atas perlu segera di atasi. Amin Abdullah menyebut bahwa untuk mengembalikan keseimbangan bobot pemikiran antara teologi Islam klasik yang lebih bermuatan moralitas-normatif dan tuntutan ilmu pengetahuan kontemporer yang bersifat empiris humanis, diperlukan kritik

${ }^{22}$ Amin Abdullah, Falsafah Kalam di Era Post Modernisme (Jakarta: Pustaka Pelajar, 1997), h. 79-83.

${ }^{23}$ Amin Abdullah, Falsafah Kalam di Era Post Modernisme., h. 54-55

${ }^{24}$ Amin Abdullah, Falsafah Kalam di Era Post Modernisme., h. 58 
epistimologis yang tajam, ${ }^{25}$ dan ini pasti tidak mudah, namun kebutuhannya sudah cukup mendesak.

Munculnya model-model pemikiran teologi modern sebenarnya adalah salah satu bentuk jawaban atas tuntutan tersebut di atas. Seperti dikemukakan sebelumnya, bahwa Teologi Modern secara nyata telah berupaya membawa masalah-masalah Ketuhanan kepada masalah kekinian yang dialami oleh manusia dengan kata lain, telah menyentuh persoalan-persoalan praktis manusia. Hal lain yang tampak pada pembahasan teologi modern yaitu sejumlah kritik tajam atau reinterpretasi atas sejumlah topic bahasan teologi klasik yang dinilai perlu dikembangkan.

Hal menarik yang perlu digaris bawahi adalah keunikan Muktazilah. Sungguhpun konten atau obyek bahasan yang diangkat oleh Mu'tazilah masih terkuak pada masalah-masalah teologi idealis klasik, namun dari segi metologi pemikirannya, kelompok ini boleh disebut sebagai telah melompat jauh melampaui zamannya. Mu'tazilah telah melakukan terobosan yang cukup berani melawan arus dengan metodologi berfikirnya yang bersifat rasional humanis. Sudah barang tentu, lagi-lagi sama dengan yang dialami oleh Ibnu Rusyd, Mu'tazilah akhirnya tinggal riwayatnya saja, sungguhpun harus diakui bahwa dari riwayat ini kemudian memberi energy positif kepada tokoh-tokoh teolog muslim modern untuk tampil menjawab tantangan zaman.

Bangkitnya pemikir-pemikir teolog dari tokoh-tokoh pemikir, dari kelompok LSM, mahasiswa melalui diskusi-diskusi dan lainya merupakan lampu hijau bagi kebangkitan bentuk baru dari falsafah teologi Islam yang diharapkan pada saatnya dapat memberi jawaban teologis terhadap masalah-masalah yang dialami oleh umat manusia di semua segmen kehidupannya.

\section{Lingkungan Hidup dalam Bingkai Falsafah Kalam.}

Dalam Bahasa Indonesia, kata atau istilah 'lingkungan' berarti (1) daerah (kawasan dsb) yang termasuk di dalamnya, (2) bagian wilayah kelurahan yang merupakan 1;ingkungan kerja pelaksanaan pemerintahan desa; 3 ) gologan atau kalangan, seperti pada kata :' ia berasal dari lingkungan bangsawan' dan 4) semua yang mempengaruhi pertumbuhan manusia atau hewan. ${ }^{26}$

Dalam pembahasan ini, makna atau pengertian yang akan dipakai adalah pengertian no. 4 dengan sejumlah pengembangan seperti yang akan diuraikan kemudian.

Kata atau istilah 'hidup' secara harfiah berarti 'masih terus ada, bergerak dan bekerja sebagaimana mestinya (tt. Manusia, binatang, tumbuhan dsb). ${ }^{27}$ Manusia dan binatang dikatakan hidup jika pada tubuhnya masih ada roh atau jiwa. Dalam pembahasan teologi Islam Klasik dan juga pada filsafat agama, persoalan hidup ini

\footnotetext{
${ }^{25}$ Amin Abdullah, Falsafah Kalam di Era Post Modernisme., h. 59

${ }^{26}$ Hasan Alwi (Eds.), Kamus Besar Bahasa Indonesia (III, Jakarta: Balai Pustaka, 2001), h. 675.

${ }^{27}$ Hasan Alwi (Eds.), Kamus Besar Bahasa Indonesia, h. 400.
} 
dibicarakan cukup panjang lebar semenatara dalam disiplin ilmu kedokteran, seseorang disebut hidup jika organ otaknya masih berfungsi.

Dalam pembahasan ini, istilah hidup mengacu pada pengertian harfiah di atas, yakni ketika obyek yang dibicarakan itu masih ada. Bergerak dan berfungsi sebagaimana apa adanya.

Gabungan dari dua kata atau istilah di atas, yakni 'lingkungan' dan 'hidup' menjadi satu istilah yang cukup populer dan penting terutama pada pertengahan abad XIX dan abad XX ini. Istilah 'lingkungan hidup' secara harfiah bermakna 'kesatuan ruang dengan semua benda, daya, keadaan dan makhluk hidup, termasuk manusia dan prilakunya yang mempengaruhi perikehidupan dan kesejahteraan manusia serta makhluk hidup lainnya. ${ }^{28}$

Dari pengertian kata di atas dapat difahami bahwa inti dari unsur lingkungan hidup itu meliputi alam, hewan dan manusia. Dalam kenyataan, kehidupan di bumi ini banyak diwarnai oleh saling pengaruh mempengaruhi antara ketiga komponen lingkungan hidup tersebut. Dengan demikian dapat disimpulkan bahwa lingkungan hidup itu merupakan keseluruhan unsur yang saling mempengaruhi kehidupan di bumi Allah swt, yang sekurang-kurangnya terdiri atas unsur alam, unsur hewani dan unsur manusia dan tingkah lakunya.

Dalam literature Islam Indonesia, perbincangan tentang "Lingkungan Hidup" dikaitkan atau ditinjau dari sudut pandang teologi Islam merupakan kelanjutan dari pengisitlahan dan pembicaraan tentang "teologi Sosial" yang dipopulerkan oleh Prof.DR.H.M. Amin Rais. Sebagai pembuka awal, sudah barang tentu Amin Rais belum terlalu pokus pada kajian khusus pada aspek-aspek social tertentu, tapi lebih mengarah pada kebangunan kesadaran bahwa dalam keseluruhan aktifitas manusia sesungguhnya tidak ada yang dapat terlepas dari dimensi ilahi.

Peristilahan Teologi Lingkungan Hidup muncul kemudian sebagai kelanjutan kesadaran tentang betapa perlunya aspek teologi ambil bagian pada seluruh lini kehidupan manusia, baik yang berskala kecil maupun yang berskala besar. Bahwa isu lingkungan hidup, sungguhpun baru mulai mengemuka pada 16 Juni Tahun 1972 dengan digelontorkannya Deklarasi Lingkungan Hidup pada Konferensi PBB di Stockholm, namun dengan kenyataan bahwa isu tentang krisis lingkungan hidup dunia (Global warning) sudah demikian mengancam dunia karena ketidak mampuan umat manusia menjaga pelestarian ekosistem, memaksa seluruh komponen untuk ambil bagian, tak terkecuali para pemuka agama-agama. ${ }^{29}$

Kalau demikian halnya, maka dapat dirumuskan bahwa Theologi Lingkungan Hidup sebagai satu bagian dari disiplin ilmu teologi mengandung makna kajian teologis atas isu-isu lingkungan hidup yang terjadi. Sudah barang tentu dengan kacamata teologi mengambil obyek kajian pada tiga aspek dasar, yaitu aspek alam, aspek hewan dan

\footnotetext{
${ }^{28}$ Hasan Alwi (Eds.), Kamus Besar Bahasa Indonesia., h. 675.

${ }^{29}$ Muchlis Muhammad Hanafi (Eds), Tafsir al-Qur'an tematik, Pelestarian Lingkungan Hidup, IV (Jakarta: Kemnterian Agama RI, 1972), h. 13.
} 
aspek manusia dan tingkah lakunya. Tak dapat disangkal bahwa saling pengaruh mempengaruhi dari tiga aspek inilah yang paling bertanggungjawab bagi terciptanya kondisi lingkungan hidup, baik yang bernada negative dengan terciptanya kondisi kehancuran ekosistem yang menyebabkan munculnya warming globe maupun yang berkaitan dengan upaya-upaya nyata dari umat manusia untuk kembali membangun dan memperbaiki ekosistem itu sendiri.

Kajian teologis atas lingkungan hidup akan memberi kesadaran kepada manusia bahwa alam dan lingkungan hidup yang diciptakan oleh Sang Maha Pencipta itu adalah nikmat yang tiada taranya bagi manusia, namun di sisi lain, juga mengandung konsekwensi tanggungjawab. Bahwa manusia diberi kesempatan untuk menikmati sebesar-besarnya nikmat itu, namun juga harus bertanggungjawab bagi pemeliharaan dan pelestariannya. Artinya adalah bahwa wewenang untuk menikmati pasilitas alam dan lingkungan ini adalah pemberian Sang Pencipta, namunh tanggungjawab untuk memelihara dan mengembangkannya juga adalah tugas penting dari Sang Pencipta itu sendiri. Dalam Bahasa sehari-hari, adalah hak dan tanggungjawab atas alam dan lingkungan hidup itu bukan hanya hak dan tanggungjawab social, namun lebih dari itu, adalah tanggungjawab syariat agama.

Dalam bahasan kalam, tanggungjawab agama berakibat dunia dan akhirat. Artinya adalah kelalaian terhadap tanggungjawab itu akan membawa konsekwensi penderitaan hidup di dunia dan kesengsaraan hidup di akhirat kelak. Dalam Bahasa sederhana dikatakan bahwa kelalaian seorang hamba menjaga kelestarian lingkungan hidup akan membawa dampak buruk pada Kehidupannya atau anak cucunya di dunia dan memikul tnggungjawab di akhirat, karena itu akan dituntut oleh Allah swt. kelak. Kalau demikian, dapat dipahami apabilka para pemuka agama-agama dengan serius turut ambil bagian dalam hal ini.

Sesungguhnya Sang Pencipta kehidupan, Allah swt. Sudah merancang kehidupan di bumi itu secara berimbang. Dalam QS al-Shaad (38):27 Allah swt. berfirman

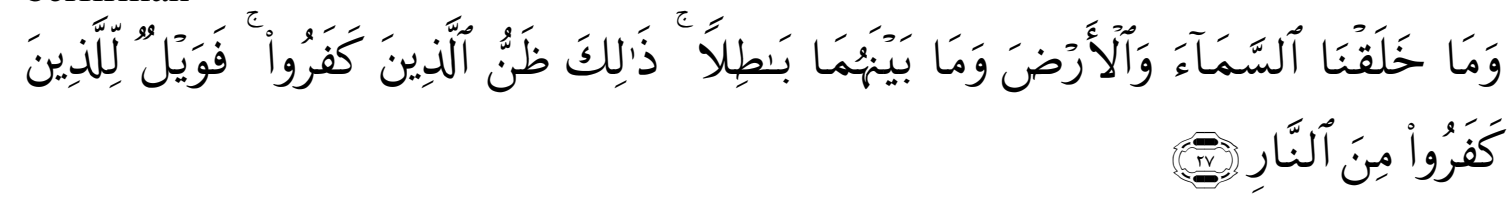

Terjemahnya:

Dan Kami tidak menciptakan langit dan bumi dan apa yang ada antara keduanya tanpa hikmah. Yang demikian itu adalah anggapan orang-orang kafir, maka celakalah orang-orang kafir itu karena mereka akan masuk neraka.

Menurut KH Abd Samad Buchori, ayat di atas memberi informasi tentang ekologi, bahwa dalam kehidupan ini, terjadi suatu tatanan kehidupan yang saling berkaitan, saling membutuhkan, saling bergantung satu dengan yang lainnya. Bahwa bila terjadi kerusakan serius pada salah satu unsur tersebut, maka akan mmberi pengaruh kepada unsur-unsur yang lain yang pada ujung-ujungnya akan menimbulkan 
ketidak seimbangan dalam kehidupan. Keadaan ini pada giliran selanjutnya akan mengancam kelestarian hidup dari seluruh komponen kehidupan itu sendiri. ${ }^{30}$

Sebaliknya, jika keseimbangan tersebut dapat terjaga kelestariannya, apakah karena terjadi secara alami ataukah karena usaha tertentu, maka kehidupan akan terjaga dengan baik dan memberi kemanfaatan kepada seluruh makhluk hidup di bumi Allah swt.

Kalau demikian halnya, maka kata kuncinya adalah, jagalah keseimbangan itu, niscaya akan memberi kehidupan yang lebih baik, lebih makmur dan lebih sejahtera.

Hal selanjutnya yang perlu distressing adalah siapkah dari ketiga unsur utama dari lingkungan hidup itu yang memiliki peran yang lebih atau paling dominan? Hampir seluruh penulis sepakat bahwa manusia dan tingkah lakunyalah yang lebih dominan. Kenapa demikian, uraian selanjutnya akan mengungkap hal tersebut.

\section{E. Manusia dan Tanggungjawabnya.}

Manusia adalah makhluk Allah yang paling unik. Manusia memiliki bentuk jasmani dan rohani yang indah dan terbaik dibanding dari makhluk-makhluk Allah lainnya (لقد خلقنا الإنسان فى أحسن تقويم). Bukan hanya wujud dan bentuknya ada, tapi manusia juga dianugerahi oleh Allah swt. Sejumlah kemampuan yang tidak diberikan kepada makhluk-makhluk Allah lainnya. Kelebihan-kelebihan yang dimiliki oleh manusia inilah yang memberinya potensi untuk menjalankan peran lebih dalam hal mempengaruhi kualitas lingkungan hidup secara keseluruhan, sungguhpun peran lebih ini boleh jadi dalam bentuk yang positif ataupun justru sebaliknya.

Uraian berikut akan menjelaskan hal tersebut. Di antara spesifikasi yang banyak diangkat adalah:

Manusia, seperti telah disinggung di atas adalah makhluk Allah yang cukup unik. Keunikannya banyak dilihat dari berbagai segi. Ia unik karena bentuk tubuhnya, unik karena kemampuan rohaninya, unik karena berani melawan perintah Tuhan dan banyak lagi.

Keunikan manusia, dalam kaitannya dengan pokok bahasan tulisan ini, banya berhubungan dengan pembahasan tentang peran atau fungsi-fungsi manusia di Bumi, sebagaimana telah banya diuraikan oleh para ahli.

Salah seorang dari para ahli tersebut, adalah. Prof.DR.H Abd. Muin Salim. Menurut Muin Salim, ada tiga jenis peran manusia di atas bumi Allah swt, yakni:

1. Manusia sebagai 'Abid

2. Manusia sebagai Khalifah

3. Manusia sebagai makhluk Pembangun.

4. Manusia sebagai Abid

Kata ' 'abid' berasal dari Bahasa Arab, yakni dari kosa kata "عبد - عبادة - عبوديّة" yang berarti 1) beribadah, 2) menyembah dan 3) mengabdi kepada. ${ }^{31}$ Dari pengertian

${ }^{30}$ Abdussomad Buchori, Konsep Islam tentang Lingkungan Hidup (Surabaya: Majelis Ulama Indonesia (MUI) Provinsi Jawa Timur, 1912), h. 9. 
kata tersebut dikaitkan dengan manusia berarti bahwa di antara kedudukan manusia di bumi ini adalah sebagai Penyembah, Pengabdi, ahli Ibadah. Alquran memastikan bahwa seluruh pengabdian, peribadatan dan penyembahan mansuia haruslah seikhlas-ikhlasnya hanya kepada Allah swt. Hal ini dipahami dari konteks firman Allah swt pada QS alBaiyyinah (98): 5 sbb.:

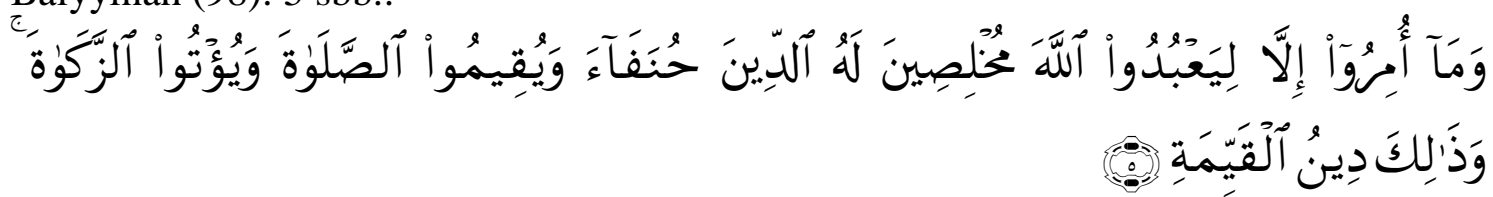

Terjemahnya:

Padahal mereka tidak disuruh kecuali supaya menyembah Allah dengan memurnikan ketaatan kepada-Nya dalam (menjalankan) agama yang lurus, dan supaya mereka mendirikan shalat dan menunaikan zakat; dan yang demikian itulah agama yang lurus.

Menurut Muin Salim, kata "عبد" pertama kali ditemukan dalam al-Qur'an pada QS al-'alaq (96): 9-10 sebagai berikut:

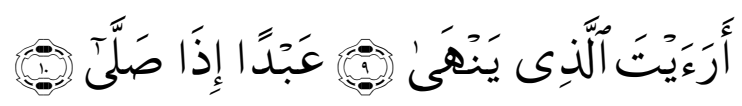

Terjemahnya:

Bagaimana pendapatmu tentang orang yang melarang. Seorang hamba ketika mengerjakan shalat.

Kemudian kata tersebut dalam bentuk kata kerja ditemukan pada QS al-Fatihah (1): 5

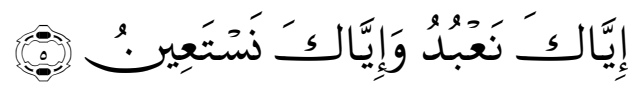

Terjemahnya:

Hanya Engkaulah yang kami sembah, dan hanya kepada Engkaulah kami meminta pertolongan.

Dari konteks ayat 5 surah al-Fatihah ini oleh para ulama, sebagaimana dikutip oleh Muin Salim, diberikan penjelasan sebagai berikut: 1) Ibnu Abbas menyatakan bahwa manusia diciptakan agar mengakui ketuhanan Allah swt Yang Esa, baik secara rela ataupun secara terpaksa. 2) Ali bin Abi Thalib menyatakan bahwa manusia diciptakan untuk diperintah melakukan beribadat kepada Allah swt. 3) Al-Raghib alAsfahani menyebutkan empat macam hamba, yakni: a) hamba karena status hukum, yakni para budak; b) hamba karena penciptaan, yakni seluruh makhluk termasuk manusia; 3) hamba karena pengabdian kepada Allah swt, yakni seluruh orang yang beriman dan beramal shaleh, dan d) hamba karena memburu dunia dan kesenangan yang ada padanya, yakni mereka yang dibutakan oleh dunia sehingga lupa Allah swt.

31 Ahmad Warson Munawwir, Kamus al-Munawwir, Arab-Indonesia (Yogyakarta: Pustaka Progressif, 1984), h. 950. 
Mereka ini yang ditunjuk oleh hadist nabi saw: 'Celakalah hamba dirham, celakalah hamba dinar, 32

Dari keterangan di atas dipahami bahwa seorang hamba, dalam hal ini manusia dalam kedudukannya sebagai 'abid' seyogyanya berkomitmen bahwa ia adalah hamba Allah swt. melakukan pengabdian, peribadatan atau penyembahan hanya kepada Allah swt saja. Sudah barang tentu hal ini menyangkut dua hal pokok, yakni pertama, keikhlasan hamba mengabdi hanya kepada Allah swt, Allah Yang Esa, dan kedua adalah kesiapan sang hamba untuk merelakan atau menundukkan sifat-sifat negative, antara lain seperti sifat berlebih-lebihan, sifat serakah, sifat dhalim yang ada pada diri mansuia kepada yang dikehendaki atau diridhai oleh Allah swt. Dengan demikian, maka sepanjang hidupnya ia hanya mau hidup sejalan dengan apa yang diizinkan, dibolehkan, diharuskan dan diperintahkan oleh Allah swt. Baik yang berkaitan dengan dirinya sendiri, berkaitan dengan Tuhannya dan berkaitan dengan makhluk Allah lainnya.

a. Manusia sebagai Khalifah

Kata atau istilah 'khalifah' sudah sangat popular di Indonesia, terutama setelah salah satu kelompok ormas Islam, yakni Hizbuttahrir Indonesia atau HTI ${ }^{33}$ gencar memperjuangkan ditegakkannya 'khilafah.' Bukan hanya dalam wilayah Negara Kesatuan Republik Indonesia (NKRI) tapi bahkan untuk seluruh dunia. Konsep-konsep pemikiran, ideology, perjuangan dan dakwah HTI dapat disimak lewat majalah bulanan, Media Politik dan Dakwah al-Wa'ie.",34 Bagi HTI, Khilafah adalah kepemimpinan umum bagi seluruh umat Islam se dunia, untuk menegakkan syariah Islam dan mengemban dakwah Islam ke seluruh dunia. ${ }^{35}$ Dalam konsep khilafah HTI, Dunia Islam wajib dipimpin oleh seorang khalifah, karena Islam adalah satu, Islam tidak mengenal batas-batas wilayah sebagaimana yang dikenal dalam sistem Negara kebangsaan. Hal ini antara lain dapat disimak dari pernyataan Amir kedua Hizbuttahrir, Syhaikh Abdul Qadim Zallum:

Mengangkat seorang khaifah adalah wajib atas kaum muslimin seluruhnya di seluruh penjuru dunia. Melaksanakan kewajiban ini sebagaimana kewajiban manapun yang difardhukan Allah atas kaum muslimin - adalah perkara yang pasti, tak ada pilihan di dalamnya dan tak ada toleransi dalam urusannya.

\footnotetext{
${ }^{32}$ Abdul Muin Salim, Konsepsi Kekuasaan Politik dalam al-Qur'an, h. 147-148.

33 HTI sekarang ini menjadi organisasi terlarang berdasarkan Peraturan Presiden tentang ORMAS tahun 2017.

${ }^{34}$ Majalah al-Wa'ie adalah media Politik dan Dakwah, Media untuk Membangun kesadaran Umat yang diterbitkan secara nasional oleh Hizbuttahrir Indonesia (HTI) dan disebarkan ke seluruh Indonesia. Majalah ini didesain cukup indah dan menarik. Kertas bagian dalam memakai kertas HVS. Rubik tetap: Pengantar, Dari Redaksi, Opini, Muhasabah, Fokus, Analisis, Afkar, Tafsir, Soal-jawab, Akhbar, Dunia Islam, Reportase, Hiwar, Siyasah Dakwahm Kesaksian dan Hadis Pilihan. Jumlah halaman, antara 70 sd. 80 dengan patokan harga: Rp. 7.500/eksemplar (harga yang berlaku sampai bulan September 2015)

${ }^{35}$ Redaksi al-Wa'ie, "Keruntuhan Khilafah Pangkal Malapetakan” dalam Majalah al-Wa'ie No 178 Tahun XV, 1-30 Juni 2015, h. 3.
} 
Kelalaian dalam melaksanakan itu termasuk sebesar-besar maksiat, yang pelakunya akan diazab Allah dengan azab se pedih-pedihnya. ${ }^{36}$

Selanjutnya, bagi HTI, negara dan syariah atau khilafah dan syariah adalah satu kesatuan yang tak dapat dipisahkan satu dari yang lainnya, bagaikan dua sisi dari satu mata uang. Artinya adalah bahwa dalam konsep ini, syariah hanya bisa ditegakkan dengan seutuhnya pada negara khilafah dan sebaliknya, tanpa negara khilafah, syariah mustahil ditegakkan sebagaimana yang terjadi di dunia dewasa ini.

Dari uraian singkat di atas, difahami bahwa kata khilafah bagi Hisbuttahrir adalah istilah yang berkaitan dengan politik, pemerintahan, kebangsaan atau keumatan.

Berangkat dari penelusuran kata atau istilah dalam bahasa Arab yang dipakai dalam Alquran, Muin Salim menyatakan bahwa kata atau konsep 'khalifah' dalam alQur'an bertalian dengan hubungan manusia dengan Allah swt dan hubungan manusia dengan lingkungannya. ${ }^{37}$ Untuk pemaknaannya itu, Muin Salim mengemukakan argumen nash sebagai berikut:

1. Firman Allah swt pada QS. Fathir (35): 39 sebagai berikut:

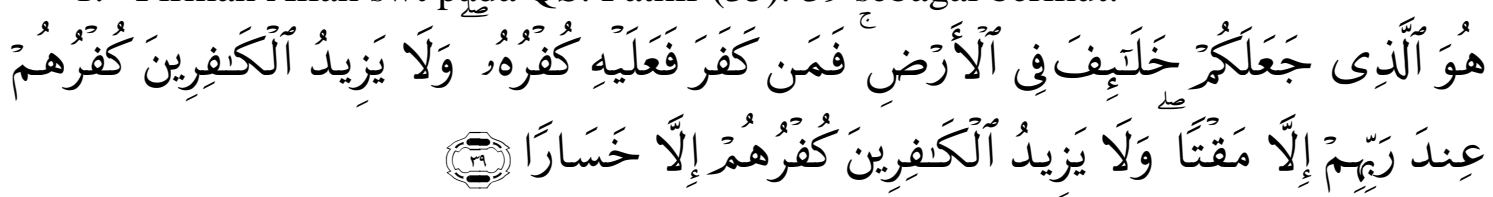

Terjemahnya:

Dialah yang menjadikan kamu khalifah-khalifah di muka bumi. Barangsiapa yang kafir, maka (akibat) kekafirannya menimpa dirinya sendiri. Dan kekafiran orang-orang yang kafir itu tidak lain hanyalah akan menambah kemurkaan pada sisi Tuhannya dan kekafiran orang-orang yang kafir itu tidak lain hanyalah akan menambah kerugian mereka belaka.

2. Firman Allah swt pada QS. Hud (11): 52/61 sebagai berikut:

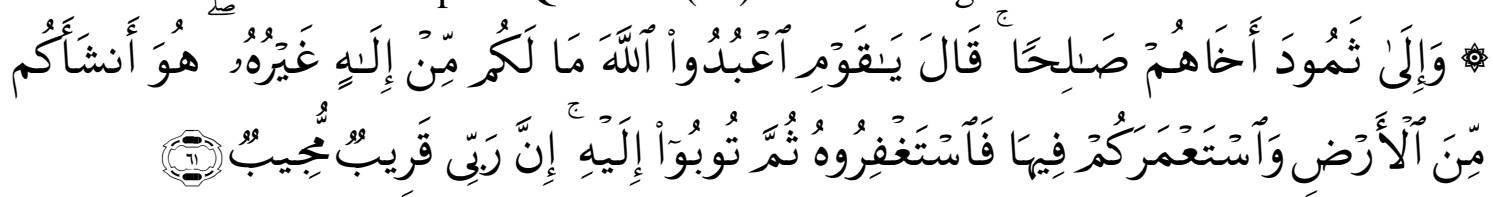

Terjemahnya

Dan kepada Tsamud (Kami utus) saudara mereka Shaleh. Shaleh berkata: "Hai kaumku, sembahlah Allah, sekali-kali tidak ada bagimu Tuhan selain Dia. Dia telah menciptakan kamu dari bumi (tanah) dan menjadikan kamu pemakmurnya, karena itu mohonlah ampunan-Nya, kemudian bertobatlah kepada-Nya, Sesungguhnya Tuhanku amat dekat (rahmat-Nya) lagi memperkenankan (doa hamba-Nya)".

${ }^{36}$ Redaksi al-Wa'ie, "Rubik Afkar: Syariah dan Khilafah untuk Rahmatan Lil "Alamin" dalam Majalah al-Wa'ie No 178 Tahun XV, 1-30 Juni 2015, h. 22

${ }^{37}$ Abdul Muin Salim, Konsepsi Kekuasaan Politik dalam al-Qur'an, h. 106-197. 
3. Firman Allah swt pada QS. al-Zariyat (51): 56 sebagai berikut:

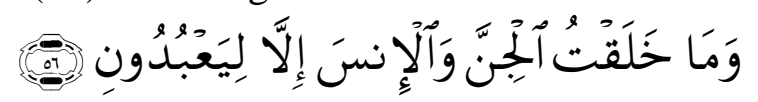

Terjemahnya:

Dan aku tidak menciptakan jin dan manusia melainkan supaya mereka mengabdi kepada-Ku.

Berdasarkan tiga ayat tersebut di atas, Muin Salim lebih mengurai kata atau istilah 'khalifah' dalam al-Qur' an sebagai berikut:

Secara etimologi, kata 'khalifah' yang berasal dari Bahasa Arab itu teruntai dari tiga huruf, yakni "خ", "ل" dan "ف", mengandung tiga makna pokok, yakni mengganti, belakang dan perubahan.

Dalam pengertian 'mengganti', misalnya ditemukan dalam al-Qur'an surah Maryam (19):59 sebagai berikut:

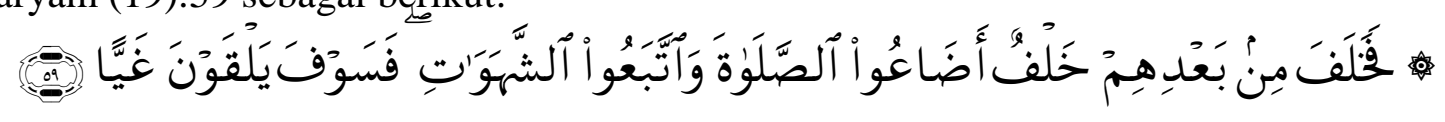

Terjemahnya:

Maka datanglah sesudah mereka, pengganti (yang jelek) yang menyia-nyiakan shalat dan memperturutkan hawa nafsunya, maka mereka kelak akan menemui kesesatan,

dan pada QS al-A'raf (7): 142 sebagai berikut:

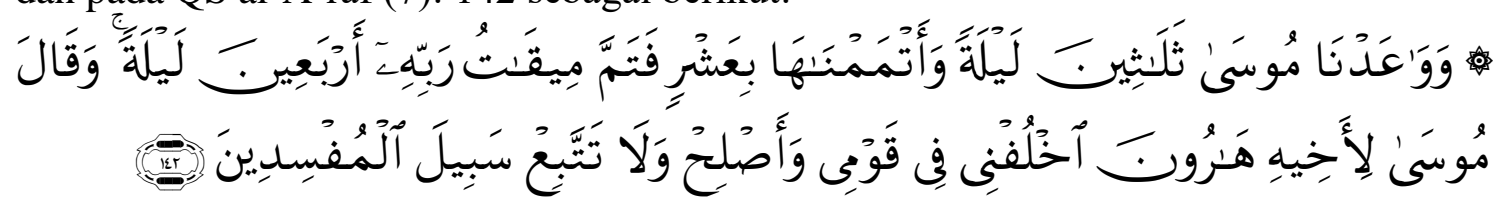

Terjemahnya:

Dan telah Kami janjikan kepada Musa (memberikan Taurat) sesudah berlalu waktu tiga puluh malam, dan Kami sempurnakan jumlah malam itu dengan sepuluh (malam lagi), maka sempurnalah waktu yang telah ditentukan Tuhannya empat puluh malam. Dan berkata Musa kepada saudaranya yaitu Harun: "Gantikanlah aku dalam (memimpin) kaumku, dan perbaikilah, dan janganlah kamu mengikuti jalan orang-orang yang membuat kerusakan".

Bentuk kata lainnya yang merupakan bentuk pengembangan dari akar kata di atas adalah "استخلف - بستخلف yang mengandung makna 'menjadikan' sehingga secara lugawi berarti menjadikan atau mengangkat pengganti. Ini bisa dilihat pada firman Allah QS al-A'raf (7): 129 sebagai berikut:

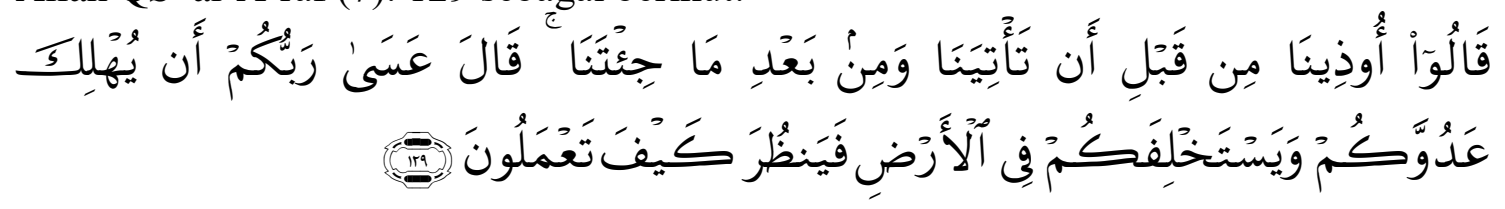


Terjemahnya:

Kaum Musa berkata: "Kami telah ditindas (oleh Fir'aun) sebelum kamu datang kepada kami dan sesudah kamu datang. Musa menjawab: "Mudah-mudahan Allah membinasakan musuhmu dan menjadikan kamu khalifah di bumi(Nya), maka Allah akan melihat bagaimana perbuatanmu.

Dan pada QS al-Hadid (57): 7, sebagai berikut:

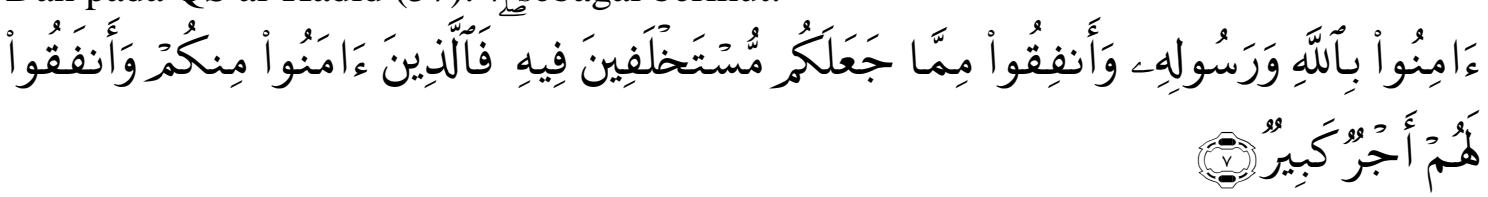

Terjemahnya:

Berimanlah kamu kepada Allah dan Rasul-Nya dan nafkahkanlah sebagian dari hartamu yang Allah telah menjadikan kamu menguasainya. Maka orang-orang yang beriman di antara kamu dan menafkahkan (sebagian) dari hartanya memperoleh pahala yang besar.

Makna spesifik dalam pengertian menjadikan atau mengangkat sebagai khalifah dengan tugas politik, dapat dilihat pada QS. Shad (38): 26 sebagai berikut:

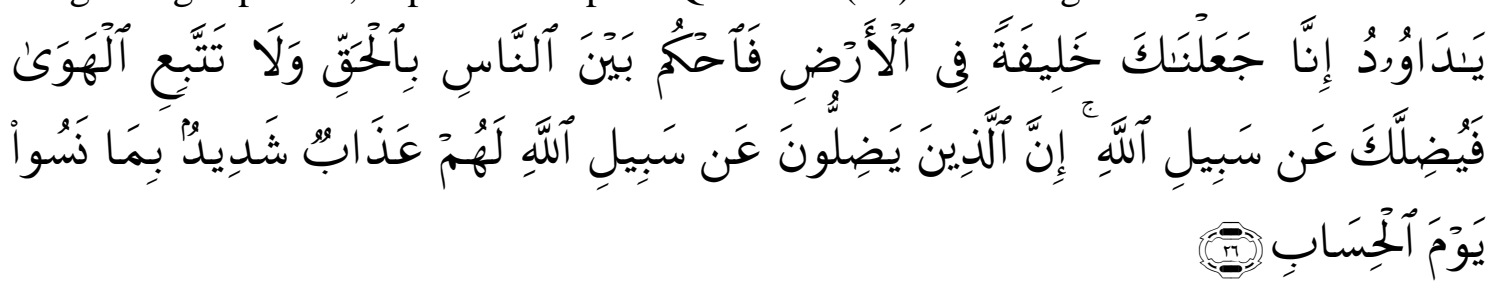

Terjemahnya:

Hai Daud, sesungguhnya Kami menjadikan kamu khalifah (penguasa) di muka bumi, maka berilah keputusan (perkara) di antara manusia dengan adil dan janganlah kamu mengikuti hawa nafsu, karena ia akan menyesatkan kamu dari jalan Allah. Sesungguhnya orang-orang yang sesat darin jalan Allah akan mendapat azab yang berat, karena mereka melupakan hari perhitungan.

Dengan mengutip keterangan ahli tafsir imam al-Qurtubi, Muin Salim menulis bahwa ayat di atas menegaskan kedudukan Nabi Daud, as. sebagai seorang khalifah Allah. Bahwa sebagai khalifah dalam pengertian pemegang wewenang untuk mengatur masyarakat, nabi Daud, as. dituntut untuk menegakkan hukum-hukum Allah di tengahtengah masyarakat dengan wanti-wanti, ia menjauhi tipu daya syaithan $^{38}$ yang berpotensi mengajak untuk melakukan penyalahgunaan wewenang, sehingga berujung pada perbuatan melanggar hukum-hukum Allah itu. ${ }^{39}$

${ }^{38}$ Dimaksud dengan tipu daya Syaithan di sini adalah mengikuti ajakan syaithan sehingga potensi negative yang ada pada manusia yang menjadi penguasa menjadi dominan seperti sifat-sifat loba, tamak, berlebih-lebihn, dhalim dan sebagainya.

${ }^{39}$ Abdul Muin Salim, Konsepsi Kekuasaan Politik dalam al-Qur'an, h. 111-112. 
Lebih jauh Muin Salim menegaskan bahwa dari pernyataan ayat di atas memberi ketegasan tentang dua hal pokok. Pertama yaitu penetapan status atau pengangkatan nabi Daud, as. sebagai khalifah dan yang kedua adalah kewajiban yang timbul dari kedudukan atau status sebagai khalifah, yaitu menegakkan hukum-hukum Allah swt. Dengan begitu maka khalifah dalam dimensi politik bermakna kepala pemerintahan yang berkewajiban untuk menegakkan hukum-hukum Allah swt. Di tengah-tengah masyarakat yang dipimpinnya dengan cara yang benar. ${ }^{40}$

c. Manusia sebagai Pembangun.

Seperti telah dikemukakan di atas, salah satu kelebihan mansuia atas makhlukmakhluk Allah swt. Lainnya adalah bahwa manusia itu diberi kelebihan berupa akal, hati dan nafs. Ketiga komponen kelebihan ini memberi kemampuan atau daya kepada manusia untuk memahami dan mengetahui hal-hal yang ada di sekitarnya, baik yang dapat dicapai oleh inderanya maupun yang tidak dapat dicapai dengan inderanya atau dalam isilah populernya 'yang ghaib'.

Karena kemampuan itu, manusia kemudian mampu menciptakan budaya dan peradaban, dan dengan peradabannya itu, manusia membina taraf kehidupannya kearah yang lebih maju. Artinya adalah, dengan peradaban manusia, mereka dapat mengubah kehidupannya ke arah yang lebih baik, lebih sejahtera, lebih makmur.

Dalam kaitan ini, al-Qur'an al-Karim memberi informasi bahwa bumi dan "هو الذي جعل لكم مافي "الأرض جميعا. Kaitan dengan tugas atau kedudukan manusia sebagai abid, dipahami bahwa Allah swt. Menyiapkan pasilitas di bumi untuk dinikmati oleh manusia dalam rangka menunaikan salah satu tugas keabidannya tersebut.

Bahwa alam semesta diciptakan oleh Allah swt. Dalam keadaan seimbang. Tata kehidupan di bumi telah Allah ciptakan secara seimbang. Kata seimbang di sini dimaknai dengan terjadinya kehidupan yang saling mendukung antara satu jenis makhluk dengan makhluk Allah lainnya yang memang sudah disunnahkan oleh Allah swt. di bumi ini. Kalau ini dibawa kepada persoalan lingkungan hidup, maka ayat ini memberi ketegasan kepada manusia bahwa manusia dengan potensi akal yang diberikan kepadanya disamping memiliki hak untuk menggunakan dan menikmatinya, sekaligus juga memiliki kewajiban untuk menjaga keseimbangannya. Memang bila keseimbangan antara unsur-unsur lingkungan hidup terjamin dengan baik, maka kehidupan di bumi ini menjadi makmur, dan seperti itulah yang dikehendaki oleh Allah swt.

Lebih spesipik lagi, dapat ditegaskan bahwa manusia sebagai makhluk berbudaya, memikul bebandan tanggungjawab lebih untuk menjaga, melestarikan dan mengembangkan kemakmuran bumi itu. Hal tersebut sejalan dengan firman Allah swt. QS. Hud (11); 61 sebagai berikut:

${ }^{40}$ Abdul Muin Salim, Konsepsi Kekuasaan Politik dalam al-Qur'an, h. 113. 


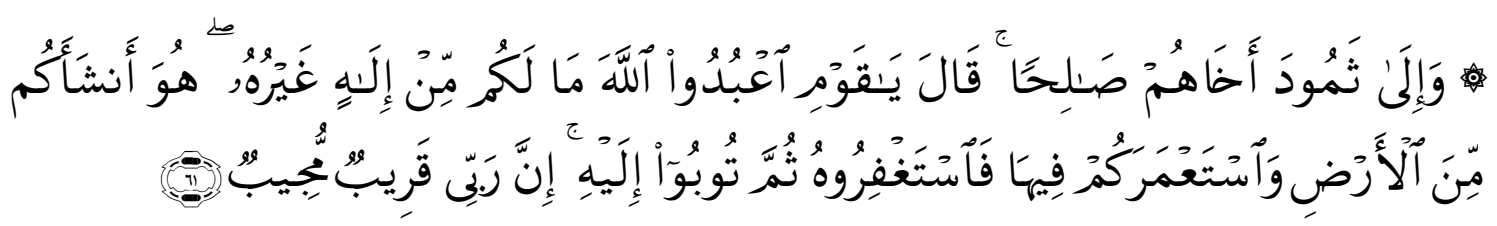

Terjemahnya:

..... Dia telah menciptakan kamu dari bumi (tanah) dan menjadikan kamu pemakmurnya, karena itu mohonlah ampunan-Nya, kemudian bertobatlah kepada-Nya, Sesungguhnya Tuhanku amat dekat (rahmat-Nya) lagi memperkenankan (doa hamba-Nya)".

Dari ayat al-Qur'an di atas dipahami bahwa penciptaan alam raya ini, termasuk bumi di mana mansusia bertempat tinggal adalah dalam sistem dan ukuran yang seimbang. Seimbang di sini bermakna seimbang dalam jumlah, dalam ukuran, dalam interaksi satu dengan yang lainnya, dan dalam keseimbangan inilah, kehidupan alam raya terjamin dengan baik. Bahwa terganggunya salah satu dari unsur-unsur tersebut akan menimbulkan ketidak seimbangan yang pada giliran selanjutnya akan merusak tatanan, siklus kehidupan dan keseluruhan dari alam raya ini.

Di Bumi, seperti dikemukakan di atas, manusia dengan berbagai kelebihannya itu mendapat amanah dari Allah swt. Untuk menjaga keseimbangan itu. Ini sesuai dengan informasi al-Qur' an al-Karim pada QS. al-Ahzab (33): 72 sebagai berikut:

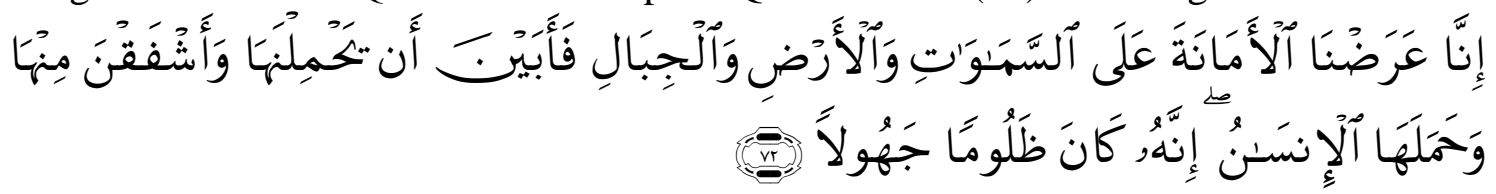

Terjemahnya:

Sesungguhnya Kami telah mengemukakan amanat kepada langit, bumi dan gunung-gunung, maka semuanya enggan untuk memikul amanat itu dan mereka khawatir akan mengkhianatinya, dan dipikullah amanat itu oleh manusia. Sesungguhnya manusia itu amat zalim dan amat bodoh,

Terjaminnya keseimbangan seluruh unsur yang ada di bumi bermakna terjaminnya kemakmuran hidup di atasnya. Artinya adalah bahwa kemakmuran tercipta di bumi bila seluruh unsur yang ada di bumi terjamin kehidupan dan keseimbangannya. Itulah sebabnya, maka salah satu tugas pokok manusia jika dikaitkan dengan kehidupan di bumi ini adalah untuk memelihara kemakmuran itu.

Dari ayat di atas jelas tergambar bahwa salah satu tugas dari keberadaan manusia di bumi ini adalah membangun kehidupan yang berwawasan lingkungan. Kehidupan berwawasan lingkungan memberi arti bahwa dalam membangun peradaban dan budayanya itu, Allah swt. memberi amanah kepada manusia untuk memakmurkan bumi dalam pengertian, sejauh apapun peradaban dan kebudayaan mannusia itu dibangun dan dikembangkan, maka ia tidak bisa terlepas dari arah menjaga dan memelihara keseimbangan kehidupan seluruh makhluk Allah di bumi. 
Bahwa hanya dengan menjaga keseimbangan kehidupan itu, maka kehidupan yang baik dan ketahanan seluruh pasilitas kehidupan itu akan terjaga kelestariannya, dan itulah yang makna yang dituju dari memakmurkan bumi.

Gambaran tentang standar kehidupan di bumi Allah swt gambarkan secara lebih terurai pada QS al-Nahl (16); 10-16 sebagai berikut:

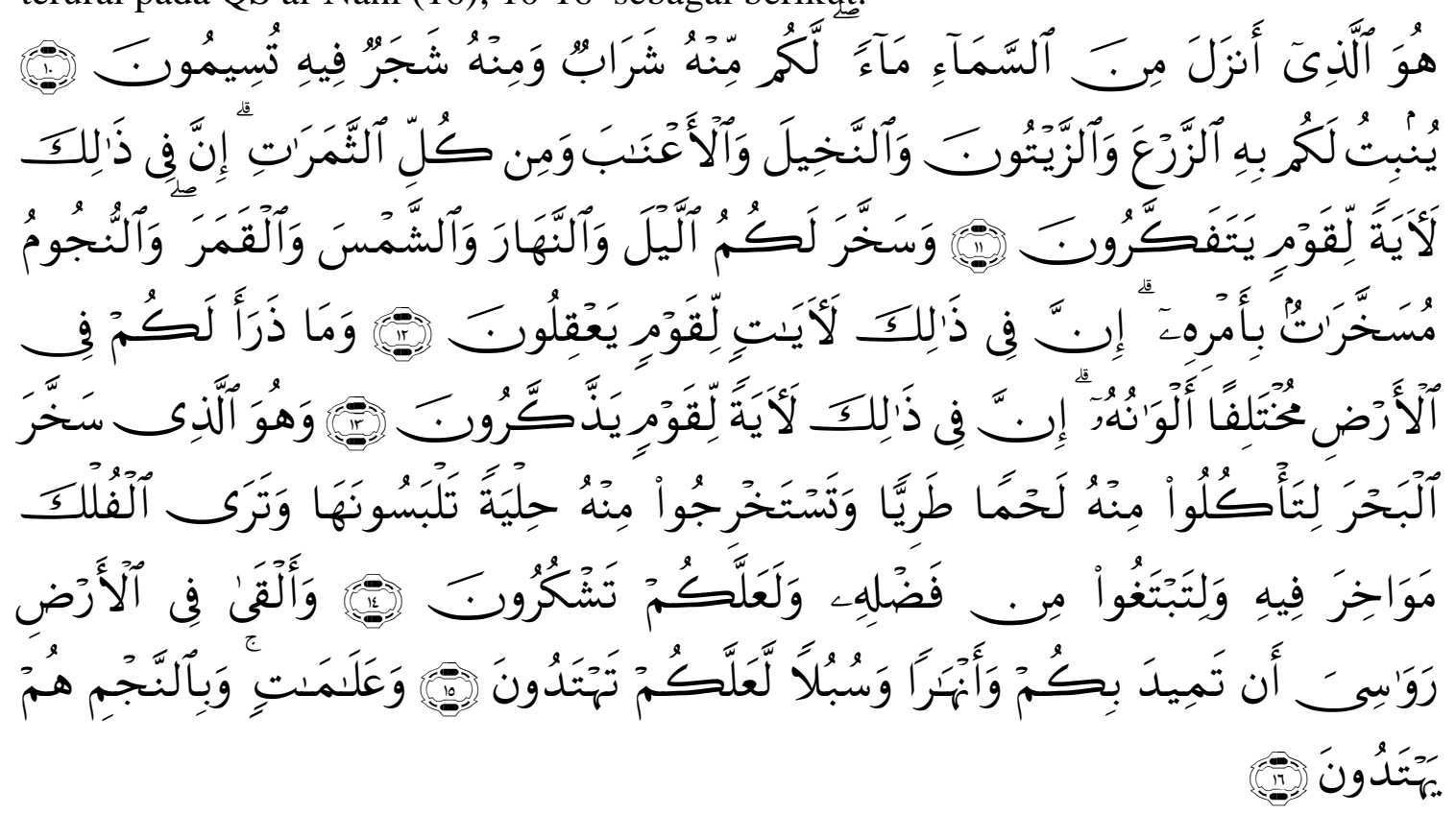

Terjemahnya:

Dialah, Yang telah menurunkan air hujan dari langit untuk kamu, sebahagiannya menjadi minuman dan sebahagiannya (menyuburkan) tumbuh-tumbuhan, yang pada (tempat tumbuhnya) kamu menggembalakan ternakmu.(10)

Dia menumbuhkan bagi kamu dengan air hujan itu tanam-tanaman; zaitun, korma, anggur dan segala macam buah-buahan. Sesungguhnya pada yang demikian itu benar-benar ada tanda (kekuasaan Allah) bagi kaum yang memikirkan (11)

Dan Dia menundukkan malam dan siang, matahari dan bulan untukmu. Dan bintang-bintang itu ditundukkan (untukmu) dengan perintah-Nya. Sesungguhnya pada yang demikian itu benar-benar ada tanda-tanda (kekuasaan Allah) bagi kaum yang memahami(nya), (12)

Dan Dia (menundukkan pula) apa yang Dia ciptakan untuk kamu di bumi ini dengan berlain-lainan macamnya. Sesungguhnya pada yang demikian itu benarbenar terdapat tanda (kekuasaan Allah) bagi kaum yang mengambil pelajaran.(13)

Dan Dialah, Allah yang menundukkan lautan (untukmu), agar kamu dapat memakan daripadanya daging yang segar (ikan), dan kamu mengeluarkan dari lautan itu perhiasan yang kamu pakai; dan kamu melihat bahtera berlayar padanya, dan supaya kamu mencari (keuntungan) dari karunia-Nya, dan supaya kamu bersyukur. (14) 
Dan Dia menancapkan gunung-gunung di bumi supaya bumi itu tidak goncang bersama kamu, (dan Dia menciptakan) sungai-sungai dan jalan-jalan agar kamu mendapat petunjuk, (15)

Dan (Dia ciptakan) tanda-tanda (penunjuk jalan). Dan dengan bintang-bintang itulah mereka mendapat petunjuk.(16)

Informasi tentang akhir kata pada tiap-tiap ayat di atas jelas menunjukkan tuntutan Allah kepada manusia agar sungguh-sungguh, tidak main-main, hati-hati dalam hal menjaga nikmat kehidupan yang seimbang itu, karena kalalaian atasnya akan memberi dampak buruk, bukan hanya bagi manusia dan kehidupannya, tapi juga atas seluruh kehidupan makhluk Allah lainnya di bumi itu. Oleh karena itulah, maka Allah swt dalam QS. Al-Qashas (28): 77 berfirman:

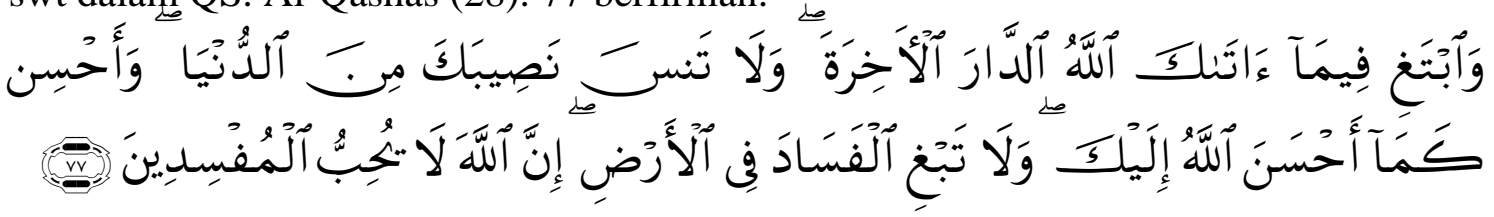

Terjemahnya;

Dan carilah pada apa yang telah dianugerahkan Allah kepadamu (kebahagiaan) negeri akhirat, dan janganlah kamu melupakan bahagianmu dari (kenikmatan) duniawi dan berbuat baiklah (kepada orang lain) sebagaimana Allah telah berbuat baik, kepadamu, dan janganlah kamu berbuat kerusakan di (muka) bumi. Sesungguhnya Allah tidak menyukai orang-orang yang berbuat kerusakan.

Dan pada QS al-Rum (30): 41 sebagai berikut:

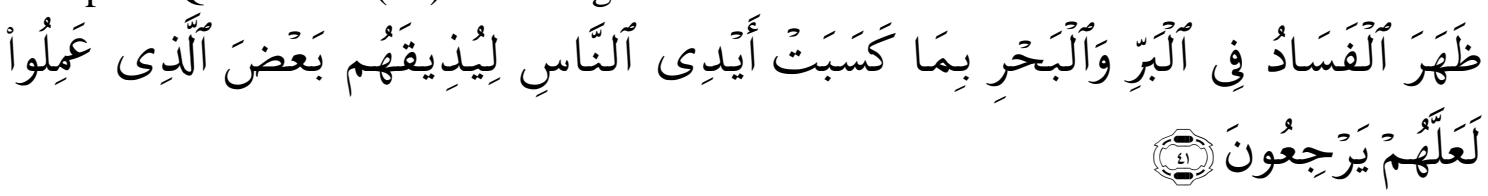

Terjemahnya:

Telah nampak kerusakan di darat dan di laut disebabkan karena perbuatan tangan manusia, supaya Allah merasakan kepada mereka sebahagian dari (akibat) perbuatan mereka, agar mereka kembali (ke jalan yang benar).

Kaitan dengan makna yang dipahami dari konteks ayat di atas, maka sebagai makhluk pembangun, manusia seharusnya memahami konsep pembangunan yang dikehendaki oleh Allah swt. Dalam hal ini, Muin Salim menegaskan bahwa konsep pembangunan manusia yang tergambar pada ayat di atas adalah konsep pembangunan secara umum, menyangkut pembangunan seluruh tatanan kehidupan di bumi. Dalam hal ini, lebih tajam Allah swt menunjukkan model pembangunan seperti yang tersurat pada QS al-Nahl (16): 97 sebagai berikut:

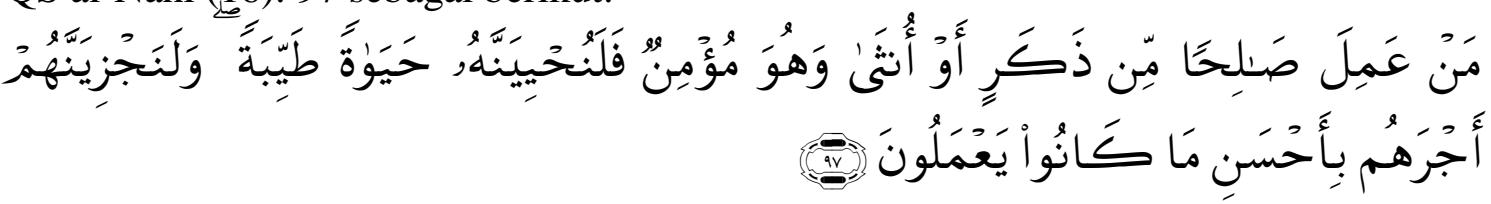


Terjemahnya;

Barangsiapa yang mengerjakan amal saleh, baik laki-laki maupun perempuan dalam keadaan beriman, maka sesungguhnya akan Kami berikan kepadanya kehidupan yang baik dan sesungguhnya akan Kami beri balasan kepada mereka dengan pahala yang lebih baik dari apa yang telah mereka kerjakan.

Muin Salim selanjutnya menyatakan bahwa manusia yang beriman dan beramal shaleh itulah yang berpotensi menciptakan model pembangunan yang dikehendaki oleh Allah swt., dan seseorang yang melakukan amal shaleh dalam hidupnya, akan berbuat sekurang-kurangnya melakukan kebaikan pada alam lingkungannya, sebagaimana alam lingkungannya itu memberi kebaikan kepadanya. ${ }^{41}$ Dalam bahasa sehari-hari, istilah untuk model pembangunan demikian disebut dengan Pembangunan Berwawasan Lingkungan. Model pembangunan yang menciptakan keseimbangan hidup bagi semua unsur-unsur hidup dan kehidupan. Model pembangunan ini dipastikan oleh Allah swt. memberi kehidupan yang sejahtera hayatan thaiyyibah, suatu model kehidupan yang diiming-iming oleh seluruh umat manusia.

Dari uraian singkat untuk tiga tugas utama manusia di bumi seperti yang dikemukakan di atas, maka dapat ditarik benang simpulannya bahwa manusia di bumi memiliki tugas ganda, setara dengan kelebihan-kelebihan dan pasilitas-pasilitas hidup yang Allah swt. anugerahkan kepadanya. Tugas ganda dimaksud adalah sebagai 'abid' dan sebagai khalifah. Sebagai abid, manusia berkewajiban melakukan hubungan baik dengan penciptanya, yakni Allah swt. Hubungan ini diwujudkkan dalam bentuk ibadah khassah seperti syahadat, shalat, puasa, zakat, haji dan lainnya. Sebagai khalifah, manusia atas nama Allah swt. dituntut untuk menegakkan hubungan manusia dengan sesamanya dengan menegakkan hukum-hukum Allah di bumi seperti keadilan, kedamaian, keramahan, dan seterusnya, maupun dengan makhluk Allah lainnya, baik yang berjiwa maupun yang tidak berjiwa, atau deng an istilah yang lebih popular, hubungan dengan lingkungan hidupnya. Dari sini muncul beberapa semboyan, misalnya, 'berbuat baiklah kepada alam, maka alam akan berbuat baik kepadamu' 'Jika engkau melakukan kejahatan kepada alam satu kali, alam akan menyengsarakan hidupmu dan generasimu seribu kali.' Hidup dengan menjaga kelestarian atau kelanggenan pada pembinaan dan pembangunan dua jenis hubungan baik seperti itulah

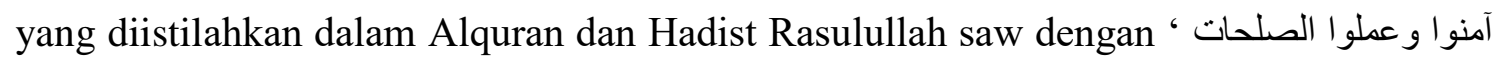

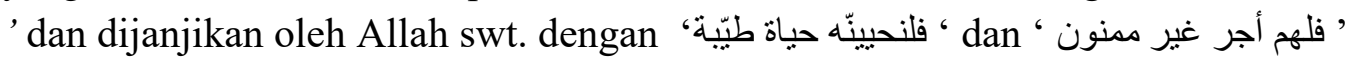

\section{PENUTUP}

1. Falsafah Kalam memperluas obyek kajiannya jauh melampaui obyek kajian filsafat dan kalam klassik, sungguhpun tidak meninggalkannya sama sekali.

2. Falsafah Kalam menarik obyeknya ke wilayah yang lebih konkrit, dan bersentuhan langsung dengan kepentingan kemanusiaan

\footnotetext{
${ }^{41}$ Abdul Muin Salim, Konsepsi Kekuasaan Politik dalam al-Qur'an, h. 124-125.
} 
3. Dalam falsafah kalam, Lingkungan Hidup bukan hanya menjadi obyek kepentingan hidup manusia, lebih dari itu, ia adalah amanah dari sang pencipta untuk dijaga keseimbangan/ kemakmurannya yang kelak harus dipertanggungjawabkan di hadapan-Nya.

4. Karena itu, kewajiban manusia sebagai makhluk berbudaya adalah mengerahkan seluruh potensi (akal dan hati) yang ada pada dirinya untuk melestarikan dan mengembangkan Lingkungan Hidup bagi kemakmuran hidup manusia di bumi sebagai sarana menunaikan tugasnya yang lain, yakni mengabdi kepada-Nya.

\section{DAFTAR PUSTAKA}

Abdullah, Amin, Falsafah Kalam di Era Post Modernisme. Jakarta: Pustaka Pelajar, 1997..

Alwi, Hasan (Eds.), Kamus Besar Bahasa Indonesia, Cet. III. Jakarta: Balai Pustaka, 2001.

Bagus, Lorens, Kamus Filsafat. Jakarta: Gramedia, 1996.

Buchori, Abdussomad, Konsep Islam tentang Lingkungan Hidup. Surabaya: Majelis Ulama Indonesia (MUI) Provinsi Jawa Timur, 1912.

Dahlan, Abdul Asiz, Sejarah Perkembangan Pemikiran dalam Islam. Jakarta: Beunebi Cipta, 1987.

Dahlan, Abdul Azis "Filsafat" dalam Taufik Abdullah (Eds.) Ensiklopedi Tematis Islam, Pemikiran dan Peradaban. Jakarta: Ichtiar Baru Van Hoeve, 2002.

Echols, John M dan Hassan Shadaly, Kamus Inggris Indonesia. Jakarta: Gramedia, 1988.

Hanafi, A, Pengantar Filsafat Islam. Jakarta: Bulan Bintang: 1976.

Hanafi, Muchlis Muhammad (Eds), Tafsir al-Qur'an tematik, Pelestarian Lingkungan Hidup,Juz IV. Jakarta: Kementerian Agama RI, 1972.

Hornby, AS (Eds.) Oxford Advanced Learner's Disctionary of Current English.

Oxford: Oxford University Press, 1986.

Husein, Oemar Amin, Filsafat Islam. Jakarta: Bulan Bintang, 1975.

Kartanegara, Mulyadi "Ilmu Kalam" dalam Ensiklopedi Tematis Dunia Islam, Jld. IV. Jakarta: Ichtiar Baru Van Hoeven, 2002.

Munawwir, Ahmad Warson, Kamus al-Munawwir, Arab-Indonesia. Yogyakarta: Pustaka Progressif, 1984.

Muslim, Shahih Muslim, "Hadist No 2 Kitab Iman” CD Ensiclopedi al-Qur'an dan Hadist, Pustaka Raihan” diunduh pada hari Ahad, 13 Juli 2015.

Nihaya, Filsafat Umum, dari Yunani sampai Modern. Makassar: T. Pen., 1999.

Salim, Abdul Muin, Konsepsi Kekuasaan Politik dalam al-Qur'an. Jakarta: Rajawali Press, 2002

Shihab, Quraisy, Wawasan Al-Qur"an. Jakarta: Mizan, 1996. 
Sou'yb, Joesoef, Perkembangan Teologi Modern. Jakarta: Rimbow, 1987.

Al-Wa'ie, "Keruntuhan Khilafah Pangkal Malapetakan" dalam Majalah al-Wa'ie No 178 Tahun XV, 1-30 Juni 2015. 